\title{
Development of a Simulation Software for Plant Asset Depreciation Computation Using Modified Accelerated Cost Recovery System
}

\author{
Basil Olufemi Akinnuli, Oluwole Timothy 0jo* \\ Department of Industrial and Production Engineering, The Federal University of Technology, Akure, Nigeria \\ Email: *wolex025@gmail.com
}

How to cite this paper: Akinnuli, B.O. and Ojo, O.T. (2018) Development of a Simulation Software for Plant Asset Depreciation Computation Using Modified Accelerated Cost Recovery System. Open Access Library Journal, 5: e4419.

https://doi.org/10.4236/oalib.1104419

Received: February 11, 2018

Accepted: March 19, 2018

Published: March 22, 2018

Copyright $\odot 2018$ by authors and Open Access Library Inc.

This work is licensed under the Creative Commons Attribution International License (CC BY 4.0). http://creativecommons.org/licenses/by/4.0/

\section{Open Access}

\begin{abstract}
This work presents the computation of depreciation under Modified Accelerated Cost Recovery System using simulation software developed for the purpose. The three case studies presented provide in-depth analysis and applications of the simulation software that was developed. The results from the three case studies proved that the investment of $\$ 900,000$ by Virgin Atlantic airline to purchase three new aircrafts will be recovered in 8 years; Toyota's investment of $\$ 152,000$ in the automated assembly line will be recovered in 8 years while AEG's investments in the two forklift trucks and crane will both be recovered in 8 years for the same reason. These results gave a quick insight for evaluating such an unstructured real life problem as depreciation (cost recovery) in organizations.
\end{abstract}

\section{Subject Areas}

Mechanical Engineering

\section{Keywords}

Simulation, Software, Plant Asset, Depreciation

\section{Introduction}

Plant Assets are fixed/tangible assets used in generation of income. They are characterized by having a useful life of more than one year, used in the operation and day-to-day running of the business and are not intended for resale to customers [1].

Plant assets are purchased for use and as such are considered as a quantity of usefulness that will contribute to the production and manufacturing operations 
of a business throughout the service life of the asset. Since the life of any plant asset other than land is limited, this quantity of usefulness or value expires due to physical deterioration as the asset is used. This expiration of an asset's quantity of usefulness is generally described as depreciation and a corresponding portion of its cost is recognized as depreciation expense [2].

Depreciation is the process of allocating asset costs over its entire life. This allocation is done in a way that the cost of the asset is charged to the accounting periods during the economics life of the asset and decreases the net value of the fixed assets [3].

Depreciation is an estimate of a decline in the value of property. Therefore, property that does not decline in value, or whose decline cannot be reasonably estimated, should not be eligible for depreciation [4].

For Industrial Engineering analysis, the depreciation process does not measure the physical deterioration of the plant asset each period, neither does it attempt to record changes in the assets market value because the market value may even increase while the process of depreciation continues anyway. Rather it is the allocation of the cost of a tangible plant asset to expense in the periods in which services are received from the asset [5].

The existence of depreciation of tangible and intangible assets is a result of two factors: the first factor is the economic and accounting expression of the (functional and physical) wear and tear of assets depending on their nature and use. The second factor stems from the fact that in the acquisition of fixed assets, it is not possible to include their cost into corporate cost [6].

Various tools are used in computing depreciation cost. One of such tools is known as "The Modified Accelerated Cost Recovery System (MACRS)", a model used for computing depreciation of most assets placed in service after 1986 mainly for tax purposes. It consists of two systems that determine how property is depreciated. The main system is the General Depreciation System (GDS) which is based on the $200 \%$ and $150 \%$ declining balance switching to straight line depreciation models. The other is the Alternative Depreciation System (ADS) which uses a longer recovery period and involves only straight line model.

This Modified Accelerated Cost Recovery System allows a corporation to elect accelerated declining balance depreciation. Relative to straight-line depreciation, declining balance depreciation allows for greater depreciation deductions during the early years of an asset's life, but smaller deductions in later years [7].

The concept of depreciation and the measurement of its value have long been a prominent issue in economic literatures, the relevance of which is demonstrated by the great number of open questions related to the subject. In the last two centuries, a good number of researchers dealt with the problem of depreciation, which not only contributed immensely to the evolution of depreciation theory, but also gave rise to many new issues. The majority of these newly encountered problems appear to be inextricable, placing the subject in what seems 
to be an endless horizon [8].

[9] worked on the impact of depreciation on costs with focus on the impact of depreciation methods on costs used in Romania. [10] examined the accounting framework of tangible assets using IFRS and US GAAP and the depreciation methods together with fair value accounting following Life Cycle Costing methodology. The results of the empirical analysis indicated that most appropriate method of depreciation is the sinking fund method which is based on a financial approach to depreciated assets only when the asset is profitable.

In spite of a good number of researches done on the calculation and computation of asset depreciation cost, there is a great need for the development of a software ideal for computing depreciation of plant assets in Engineering Economy. The simulation program is a useful tool for managerial decision making. Hence, this work focuses on the development of a simulation software to compute plant asset depreciation using Modified Accelerated Cost Recovery System (MARCS).

\section{Methodology}

The step-by-step procedures adopted for building the simulation model for this work entails the following steps: Problem definition, identifying decision variables and set objectives, Developing the simulation model, Test and validate the model, Design the simulation experiment, Run the developed simulation, Evaluate the results.

\section{Simulation Flowchart}

For ease of understanding the flowchart which is presented in Figure 1, the definition of parameters used in the flowchart is as follows.

Let: MACRS GDS = MACRS General Depreciation System

MACRS ADS = MACRS Alternative Depreciation System

$\mathrm{L}=$ Asset class life

$\mathrm{N}=$ Recovery period

Drn $=$ Depreciation rate for $n$th year

$F c n=$ First Cost for nth year

Den $=$ Depreciation Expense for $n$th year

Adn $=$ Accumulated Depreciation for $n$th year

Adn-1 = Accumulated Depreciation for $(n-1)$ th year

$B n=$ Book value (or Basis) for nth year

$Y n=$ nth year

$S V=S c r a p$ value, Salvage value, or Residual value

The modeling language used for the simulation program is FORTRAN 95 with Salford FTN 95 Compiler.

\section{Results and Discussion}

In this research, three case studies were used to test the developed simulation software as seen in Table 1, Table 3 and Table 5 respectively. These case studies 


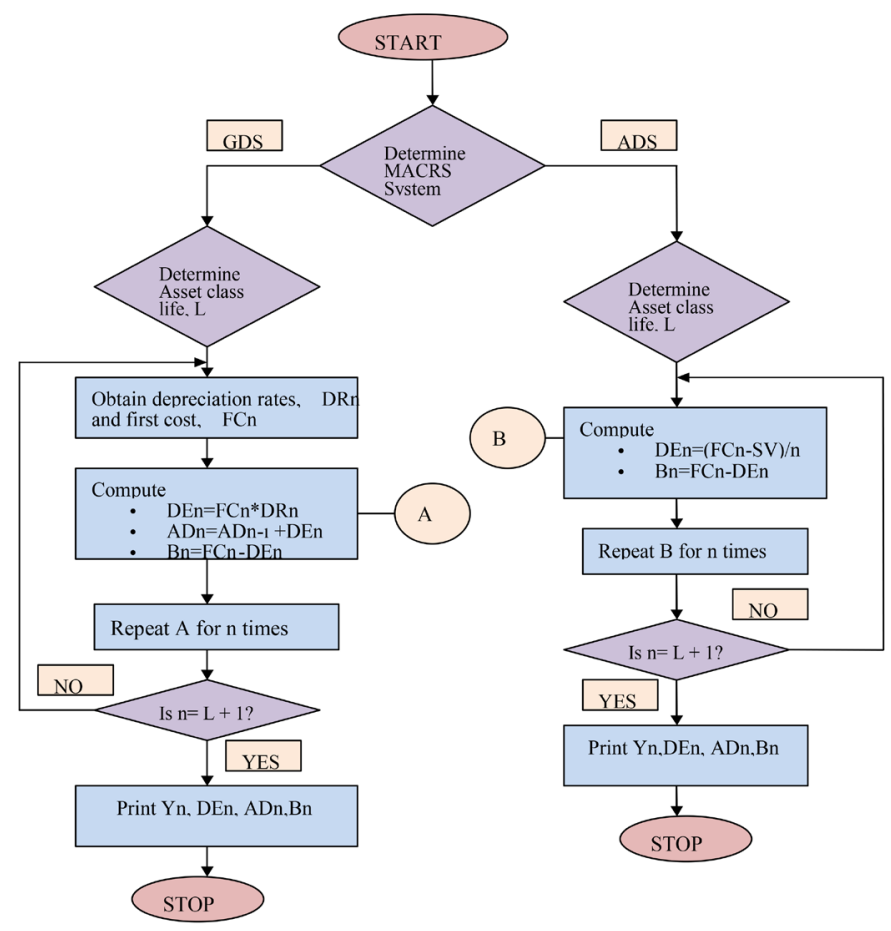

Figure 1. The simulation flow chat.

Table 1. First case study (Virgin Atlantic Airline).

\section{CASE 1}

Virgin Atlantic airline is considering the purchase of 3 new passenger aircraft. This aircraft has the capacity of 400 passengers at an expected load factor value of 0.95 . A fare of $\$ 275$ one-way will be charged and the air plane will make an expected 300 one-way crossings per year. The aircraft will cost $\$ 900,000$ each. Operations and maintenance expenses will be $\$ 727,500$ per year. It is estimated that this major purchase will yield an increase of $\$ 120,000 /$ year in gross income. Resale value of the air craft will be $\$ 350,000$. Depreciation under MACRS is over a life of 7 years. The airline is in the $46 \%$ tax bracket. Management wants to report the highest possible earnings to stockholders in the near future, yet also wants to minimize taxable income. What will be the MACRS depreciation deduction recorded for the period under review?

Table 2. The MACRS depreciation schedule for virgin Atlantic airline.

Please, enter value for the first cost in thousands

900

What is the recovery period?

7

\begin{tabular}{cccc}
\hline Year & Dep. Expense & Acc. Deprec. & Book value \\
1 & 128.61 & 128.61 & 771.39 \\
2 & 220.41 & 349.02 & 550.98 \\
3 & 157.41 & 506.43 & 393.57 \\
4 & 112.41 & 618.84 & 281.16 \\
5 & 80.37 & 699.21 & 200.79 \\
6 & 80.28 & 779.49 & 120.51 \\
7 & 80.37 & 859.86 & 40.14 \\
8 & 40.14 & 900.00 & 0.00
\end{tabular}

Press RETURN to close window ... 
Table 3. Second case study (Toyota Motor Corporation).

CASE 2

Toyota Motor Corporation recently acquired a subsidiary auto company and plans to revamp its old automobile plant. It was perceived that even with the present workforce, building and technology at this subsidiary plant, productivity was gradually declining. To meet rising demand, Toyota wants to expand output and increase sales by investing in an Automated Assembly line to produce vehicles of higher quality, at a lower cost, and with less pollution. The initial cost of this innovative technology will be $\$ 140,000$, with an installation cost of $\$ 12,000$, an economic life of 15 years and a residual value of $\$ 29,000$. The Company's Management wants to know the MACRS depreciation schedule for use in the manufacturing accounts and in making income projections for the proposed investment.

are Virgin Atlantic Airline, Lagos; Toyota Motor Corporation, Lagos and AEG, an Engineering firm base in Lagos, Nigeria. The results obtained from the analysis of these case studies using the simulation software developed are presented respectively and discussed in detail.

From the information given in Table 1, the First Cost, $\mathrm{FC}=\$ 900,000$, Asset class life, $\mathrm{L}=7$ years.

Recovery period, $\mathrm{n}=8$ years, Salvage Value $=\$ 350,000$.

The parameters in Table 1 were used in the simulation software model developed and the program was executed. For each aircraft, the MACRS depreciation schedule is presented in Table 2.

The results obtained as presented in Table 2 shows that should Virgin Atlantic decide to purchase the new aircrafts, the company will be investing $\$ 900,000$ each for the 3 aircrafts $(\$ 2,700,000)$ to obtain a quantity of transportation for their daily operations. The recovery period is 8 years due to MACRS half-year convention. This implies that this quantity of transportation will expire in 8 years after which the aircrafts will be replaced to ensure safety of lives in their daily operations. The MACRS depreciation expense (in thousands) for each year will then be recorded as depreciation deduction for the aircrafts in the company's balance sheets. The tax effects of this MACRS depreciation schedule shows that lower taxes are paid in the earlier years up to the $5^{\text {th }}$ year when the tax payment becomes constant till the $7^{\text {th }}$ year and then increased in the last $\left(8^{\text {th }}\right)$ year as depreciation expense dropped to $\$ 40,140$.

Similarly, from the information given in Table 2, the First Cost, FC = $\$ 152,000$, Asset class life, $\mathrm{L}=7$ years, Recovery period, $\mathrm{n}=8$ years, Salvage value $=\$ 29,000$.

The above parameters were used in the simulation software model developed and the program was executed. For the automated assembly line, the MACRS depreciation schedule is presented in Table 4.

The output from Table 4 shows that the first cost of $\$ 152,000$ ( $\$ 140,000$ plus $\$ 12,000)$ to be invested in the automated assembly line will be recovered in 8 years instead of 7 years due to MACRS half-year convention. The MACRS depreciation expense (in thousands) for each year will also be recorded as depreciation deduction for the automated assembly line in the company's balance 
sheets. The tax effects of this MACRS depreciation schedule implies that lower taxes are paid in the earlier years up to the $7^{\text {th }}$ year when the tax payment becomes constant till the $15^{\text {th }}$ year and then increased in the last $\left(16^{\text {th }}\right)$ year as depreciation expense dropped to $\$ 4480$.

From the information given in Table 5, the first cost for the crane, $\mathrm{FC}=\$ 10,000$ $+\$ 7000=\$ 17,000$, asset class life, $\mathrm{L}=7$ years, Recovery period, $\mathrm{n}=8$ years.

Table 4. The MACRS depreciation schedule for the automated assembly line.

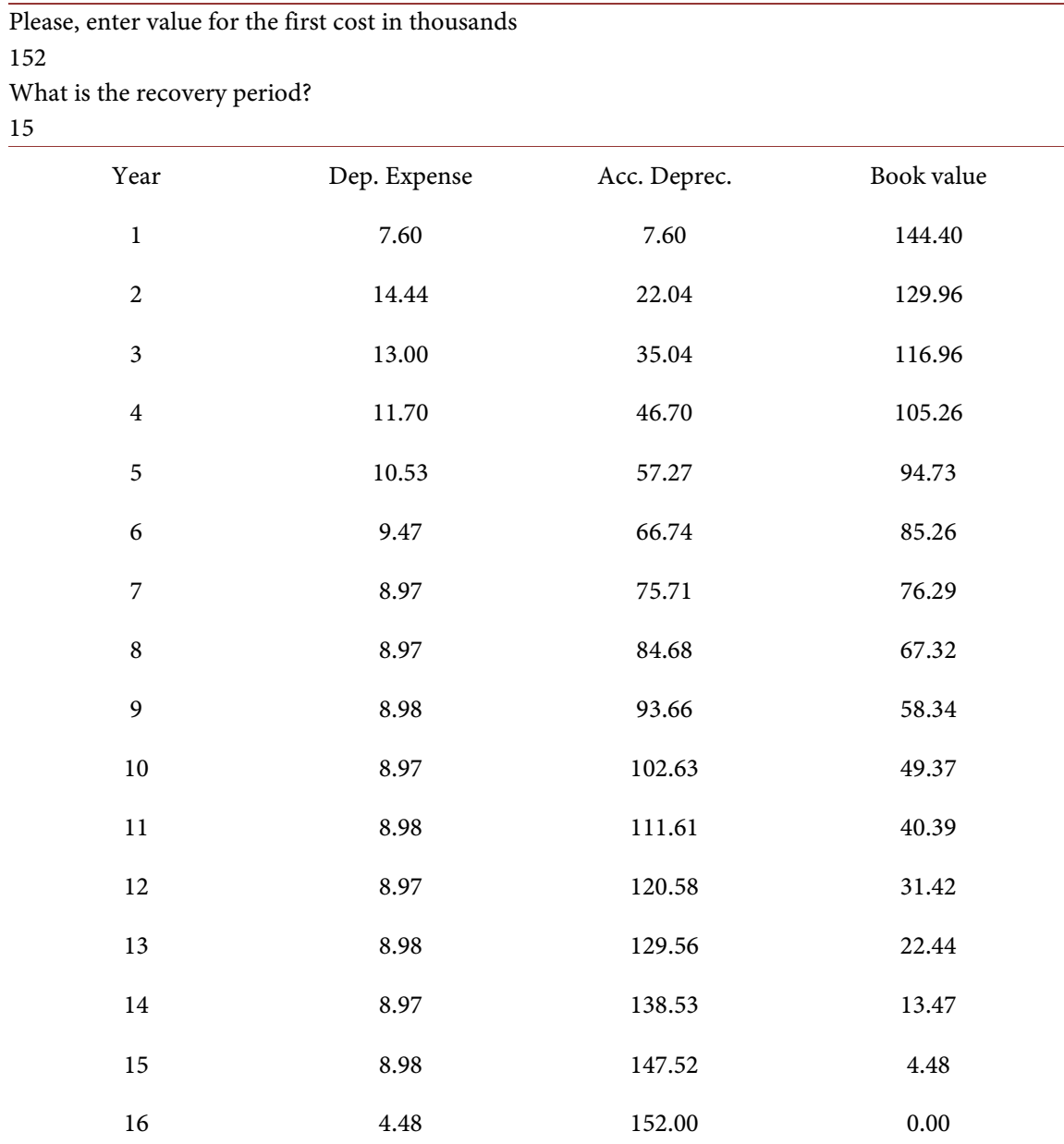

Press RETURN to close window ...

Table 5. Case study 3 (AEG, Engineering Firm).

\section{CASE 3}

AEG, an engineering firm, is considering investing in material handling equipment-a new crane and two new forklift trucks to transport large pallets of in-process materials from department to department. It is estimated that these will reduce annual operating cost by $\$ 9000 /$ year over a 10 year planning horizon. At present the materials are transported on manually operated low lift platform trucks. The total worker-hour required per year will also be reduced from 6000 hours to 2000 hours if the forklift is purchased. The forklift will cost about $\$ 25,000$ and have an economic life of 7 years with a zero-estimated salvage value. The crane will cost about $\$ 10,000$ with an estimated installation cost of $\$ 7000$ and an economic life of 7 years. What is the combined deprecation deduction that will be made to overhead cost in the company's manufacturing account? 
The above parameters were used in the simulation software model developed and the program was started. The output of the MACRS depreciation schedule for the crane is as shown in Table 6.

First cost for the fork lift trucks, $\mathrm{FC}=\$ 25,000^{\star} 2=\$ 50,000$, Asset class life, $\mathrm{L}=$ 7 years, Recovery period, $\mathrm{n}=8$ years, Salvage value $=\$ 0$.

The output of the MACRS depreciation schedule for the forklift upon successful execution of the simulation program is shown in Table 7.

The output in Table 7 shows that the first cost of the crane, $\$ 17,000$ ( $\$ 10,000$ plus $\$ 7000$ ) will be recovered over an 8 year planning horizon instead of 7 years due to MACRS half-year convention. Similarly, the first cost of the 2 new forklift trucks, $50,000\left(\$ 25,000^{\star} 2\right)$ will be recovered in 6 years instead of 5 years for the same reason. Their combined MACRS depreciation expense will be reflected yearly in the balance sheets until the $8^{\text {th }}$ year.

Table 6. Output of MACRS depreciation schedule for the crane.

\begin{tabular}{|c|c|c|c|}
\hline $\begin{array}{l}\text { Please, enter val } \\
17 \\
\text { What is the rec } \\
7\end{array}$ & t cost in thousa & & \\
\hline Year & Dep. Expense & Acc. Deprec. & Book value \\
\hline 1 & 2429.30 & 2429.30 & $14,570.70$ \\
\hline 2 & 4163.30 & 6592.60 & $10,407.40$ \\
\hline 3 & 2973.30 & 9565.90 & 7434.10 \\
\hline 4 & 2123.30 & $11,689.20$ & 5310.80 \\
\hline 5 & 1518.10 & $13,207.30$ & 3792.70 \\
\hline 6 & 1516.40 & $14,723.70$ & 2276.30 \\
\hline 7 & 1518.10 & $16,241.80$ & 758.20 \\
\hline 8 & 758.20 & $17,000.00$ & 0.00 \\
\hline
\end{tabular}

Press RETURN to close window ...

Table 7. Output of the MACRS depreciation schedule for the forklift.

\begin{tabular}{|c|c|c|c|}
\hline \multicolumn{4}{|c|}{$\begin{array}{l}\text { Please, enter value for the first cost in thousands } \\
50\end{array}$} \\
\hline Year & Dep. Expense & Acc. Deprec. & Book Value \\
\hline 1 & 7.15 & 7.15 & 42.85 \\
\hline 2 & 12.25 & 19.39 & 30.61 \\
\hline 3 & 8.74 & 28.14 & 21.86 \\
\hline 4 & 6.24 & 34.38 & 15.62 \\
\hline 5 & 4.46 & 38.85 & 11.15 \\
\hline 6 & 4.46 & 43.30 & 6.70 \\
\hline 7 & 4.46 & 47.77 & 2.23 \\
\hline 8 & 2.23 & 50.00 & 0.00 \\
\hline
\end{tabular}




\section{Conclusion}

A simulation software to compute plant asset depreciation using Modified Accelerated Cost Recovery System (MARCS) has been developed. The results from the three case studies proved that the investment of $\$ 900,000$ by Virgin Atlantic airline to purchase three new aircrafts will be recovered in 8 years due to MACRS half year convention; Toyota's investment of $\$ 152,000$ in the automated assembly line will be recovered in 8 years while AEG's investments in the two forklift trucks and crane will both be recovered in 8 years for the same reason. A cursory look at the benefits of MACRS for tax purposes over other depreciation models as well as its rapid write-off of assets in the earlier years of the asset's life shows that it is ideal for computing depreciation of plant assets in engineering economy. The simulation program is a useful tool for managerial decision making in this study area because of its relevance in areas of applications such as: Long range planning for purchase and replacement of plant assets used in manufacturing operations, Computing depreciation deductions in any given period for tax purposes in manufacturing accounts and taxable income in balance sheets of corporations, Financial analysis in industrial engineering, Operations research, Engineering economics as well as in cost engineering.

\section{Acknowledgements}

The Authors would like to acknowledge Adebayo, Afolabi Victor who contributed immensely to the success of this work.

\section{References}

[1] Galbreath, S., Caldwell, C., Booker, J. and Rooney, C. (2011) Plant Assets, Natural Resources and Intangibles. The McGraw-Hill Companies, Inc., New York.

[2] Larson, K. and Miller, P. (1992) Financial Accounting. IRWIN, Homewood.

[3] Davis, L. (2007) Life Cycle Costing as a Contribution to Sustainable Design: A Common Methodology_Final Report. Management Consulting, London.

[4] Richard, K. (1998) Depreciation, Amortization and Depletion, Tax Law Design and Drafting, International Monetary Fund. 2.

[5] Meigs, R., Meigs, M., Bettner, M. and Whittington, R. (2003) Financial Accounting. IRWIN/McGraw-Hill, Boston.

[6] Stareva, M. and Cermakova, H. (2010) Method of Component Depreciation of Fixed Assets and Its Comparison with Traditional Methods. Agris On-Line Papers in Economics and Informatics, 2, 37-46.

[7] Hartman, J., Liedtka, S. and Snyder, L. (2007) The Impact of US Tax Depreciation Law on Asset Location and Ownership Decisions. Computers and Operations Research, 34, 3560-3568. https://doi.org/10.1016/j.cor.2006.01.020

[8] Nandor, K. (2013) Examination of Phenomena Affecting the Depreciation of Fixed Assets. PhD Dissertation, Management and Business Administration PhD Programme, Corvinus University of Budapest, Budapest.

[9] Radu, M. (2013) The Impact of Depreciation on Costs. Annals of the University of Petroşani, Economics, 13, 251-260. 
[10] Liapis, K. and Kantianis, D. (2015) Depreciation Methods and Life Cycle Costing Methodology. Procedia Economics and Finance, 19, 314-324.

https://doi.org/10.1016/S2212-5671(15)00032-5 